\title{
Sentani Watershed Erosion Potential Study and Suspended Solid Distribution (TSS) In Connection With Lake Silting
}

\author{
Yusup Bungkang ${ }^{1 *}$, Soemarno ${ }^{2}$, Diana Arfiati ${ }^{3}$, Moh. Bisri $^{4}$ \\ ${ }^{1}$ Doctoral Program of Agricultural Science, Faculty of Agriculture, University of Brawijaya, Indonesia \\ ${ }^{2}$ Faculty of Agriculture, University of Brawijaya, Indonesia \\ ${ }^{3}$ Faculty of Fisheries and Marine Sciences, University of Brawijaya, Indonesia \\ ${ }^{4}$ Faculty of Engineering, University of Brawijaya, Indonesia
}

\begin{abstract}
This study aims to analyze the problems that occurred in the area of Sentani Lake, including the erosion in the watershed, increased the sediment deposition and its relation to the silting up of the lake. The purpose of this study is to provide information to stakeholders, especially related to the preservation of Lake Sentani.

These study results explained that the Lake Sentani experiencing silting caused of the deposition of sediment. Results of the mapping erosion potential is to provide information that the highest erosion potential of between 60 to 180 tons per hectare per year in the north of the lake, they are areas that have a high degree of slope. The lake of suspended solids concentration (TSS) between the top layer and the bottom layer there are significant differences in the upper layer of the TSS concentrations ranging from 20 milligrams per liter to 320 milligrams per liter while the bottom layer of the TSS concentrations ranged from 80 milligrams to 410 milligrams per liter liter.

TSS concentration in the top layer at the inlet is significantly different from the TSS concentration in the outlet at the inlet ranged from 300 milligrams per liter to 320 milligrams per liter, while in the outlet TSS concentrations ranged from 20 milligrams per liter to 50 milligrams per liter. TSS concentration in the bottom layer at the inlet is significantly different from the TSS concentration in the outlet at the inlet ranged from 350 milligrams per liter to 390 milligrams per liter, while in the outlet TSS concentrations ranged from 80 milligrams per liter to 170 milligrams per liter, while in the middle of the lake that is the ultimate in having the highest TSS concentrations ranged from 390 milligrams per liter to 410 milligrams per liter.

Water flow rate was measured on two layers near the surface and near the bottom of the lake. There is a significant difference between the flows rates in the second layer, which is the rate of flow in the upper layer ranged from $6 \mathrm{~cm}$ to $22 \mathrm{~cm}$ per second per second while the bottom layer ranged from $2.7 \mathrm{~cm}$ to $16 \mathrm{~cm}$ per second per second. The flow rate in the two layers have different characteristics, the flow rate in the upper layer has greater ranging from the inlet toward the outlet of the lake while the flow in the bottom layer from the inlet to the lake center the flow rate increases.
\end{abstract}

Keywords: erosion, TSS, sediment deposition, siltation of the lake.

\section{Introduction}

Lake is one of the smallest ecosystem on the earth's surface compared to aquatic and land habitats. Lake ecosystems are needed both on the human aspects of socio-ecological values and socio-economic. One form of designation around the lake area was converted to accommodate variety of human activities such as settlements, roads, sewerage household, agricultural land, recreation and so on (Collen \& Miller, 1995). Therefore, happens unbalancing between utilization and conservation of the lake, where utilization of the lake is more dominant in natural resources and watershed areas. The result is succession of the lake condition, which is changing from the aquatic to a terrestrial ecosystem. The siltation due to erosion and eutrophication are causing of succession on lake's water. The loss of the lake ecosystem result the lackness of ground water reserves in an area/ region that will threaten the availability of clean water for human beings and other living things. As the result, sustainability of an environment involves human beings and natures are not going to sustain.

Global concern to the lake problems are described by Jorgensen (2009) who stated that the lake problems around the world among others : (a) the high sedimentation in lakes and water reservoirs due to soil erosion or uncontrolled of the land utilization on the watershed; (b) detection of lake acidification process due to acid rain which is disturb the fisheries and ecosystem degradation; (c) degradation of water quality caused of water waste pollution, organisms with toxic contaminants or toxic substances derived from agricultural waste and industrial waste; (d) the emergence of eutrophication process because the inclusion compounds of nitrogen and/ or phosphorus result of industrial activity, agricultural, domestic, and other surface run off, and cause flare or " bloom " on the phytoplankton, water pollution and loss of biodiversity, and (e) the changing of total (completetly collapse) on aquatic ecosystems in extreme cases. Therefore, required sinergic cooperation 
between stakeholders and thorough comperhensive review of the problems and the handling of eutrophication in the lake areas as the integrated implementation management of natural resources and manifested into guidelines for the lake management. As the result, environmental conservation involves human and nature are remain guaranteed.

Lake as technically serves as a source of raw water, where a variety of aquatic life, regulating and balancing water management, flood control and river power plants and others. In addition, the lake has multi function characteristics, namely the function of ecological, economic, environmental, social, cultural, and religious. Therefore, through the Bali Agreement on Sustainable lake management purposed to maintain, preserve and restore the function of lakes and water reservoirs based on the principle of ecological balance and the carrying capacity of its environment. Commitments from nine departments through a seven-point of strategic program signed by four ministers at National Conference Lake of Indonesia, with the theme " Lakes Management and Anticipated of Climate Change" in Denpasar, Bali Province, on 13-15 August 2009.

International Lake Environment Committee or ILEC reaffirmed the principle of the lake visions, among others: (1) the harmony of relationship between human and nature or the environment, (2) the catchment area of the lake area is the starting point of watershed management, (3) long-term approach to prevent of lake damage, (4) the using of science and technology for development and policy-making; (5) sustainability principles to avoid conflict; (6) society and stakeholder participation, and (7) governance based on fairness, transparency and empowerment of all stakeholders. The seventh vision suggests that the presence of lake ecosystems contribute functions to create prosperous of human life, namely the activities of domestic, industrial, and agricultural. Although compared with aquatic and terrestrial habitats, lakes and water reservoirs are ecosystem that occupies a relatively small area on the surface of

the earth.

Indonesia has more than 500 lakes with a total area of over $5,000 \mathrm{~km} 2$ or about $0.25 \%$ of the land area of Indonesia (Davies et al., 1995), but the condition status of most of the lake lately has been very poor. At this moment the function and perceived benefits of the lake has been on the wane. This is reinforced by an explanation of the Minister of the Environment National Conference Lake in Indonesia II (KNDI II) October 13 to 14, 2011 in Semarang, that there are 15 lakes that require immediate action for recovery. The problems are the high rate of sedimentation of the upper reaches of the river, which causes narrowing and shallowing of the lake, the effects of climate change and the need for government's commitment to monitoring and maintaining the sustainability of each lake. The lakes are included in the 15 priority lakes one of them is Sentani Lake.

Lake Sentani is located in the southern town of Sentani covering Sentani district, Ebungfau, Waibu, and East Sentani. Sentani Lake has an area of 9630 hectares (ha) and a depth of $70 \mathrm{~m}$ above sea level is one unit with Cycloops Mountains Nature Reserve (Jayapura) that is large in 245,000 ha. Cycloops Mountains bordering Jayapura city set into a nature reserve. Materplan of Sentani Lake Maintenance, 2012, explained that the Sentani Lake has an important role for the Jayapura City and the surrounding areas as it has multifunctional. Sentani Lake ecologically has several functions, including: (1). as flood control. Sentani Lake has function to minimize the flood when rain comes because the area in the upper lake to the north and east of the catchment topography is steep trees (forest) and partly overgrown with grass. At the time of heavy rains, especially areas not covered by trees, heavy flow will occur that can cause flooding. The area is located on the bottom of the Sentani Lake is a low-lying valley Tami include cropland. Runoff water that flows from the upper area (catchment area) of the lake will be accommodated in the lake, so the lake serves as a regulator of the flow of water so that the lowlying land protected from floods, (2). Jayapura City of Papua province and surrounding areas prone to earthquakes, therefore the water is collected in Sentani Lake also serves as a vibration damper earthquakes because seismic waves from the earthquake rate slowing (attenuation) when compared to the rate of water passing seismic waves passed solids (soil and rock), (3). Sentani Lake managed by three districts namely Jayapura City, Jayapura Regency, and Keerom Regency for various purposes, such as clean water sources for nearby residents, irrigation, fisheries, tourism, and transportation. Currently government of Jayapura City has been programmed to make the Sentani Lake as a tourist attraction and a source of energy Hydroelectric Power Plant (HEPP) for the Jayapura city and the surrounding areas.

Sentani Lake ecologically has some functions needed to preserve the funds in the long term. Management of Sentani Lake order to remain sustainable, it must involve multi-stakeholders, among others: (1) entrepreneurs, both of in the lake region and outside the lake region, (2) the Government, the Local Government, Department of Fisheries, and Forestry Department, (3) High school, (4) Governmental public/Foundation environmental, and general public, both fishermen and non-fishermen communities. Other factors that determine the success of the lake managements are: human resource, organizational, institutional, regulatory, and infrastructure.

This study aims to analyze the problems that occur in the ecosystem of Sentani Lake, including the erosion in the watershed, increased sediment deposition and its relation to the silting up of the lake. The purpose 
of this study is to provide information to stakeholders in this area, especially related to the preservation of Sentani Lake. Related with the achievement of the objectives done based on research activities consist of: (1) Mapping the potential for erosion and watershed Sentani (2). Mapping the distribution of sediments in Sentani Lake.

\section{Research Methods}

\section{Water Sampling}

Water samples for the purposes of TSS concentration data taken at three levels of depth in the layer near the surface of the lake (top layer), a layer of mid and the layer near the bottom of the lake (bottom layer). Analysis of water samples to obtain data TSS concentration of Chemistry laboratory, Cendrawasih University Jayapura. Sekunser data is required to determine of the potential erosion of the watershed was obtained through various related department such as the BMKG Jayapura to obtain rainfall data, and Forestry Regional Office of Public Works to obtain data on slope, soil type, land management and NDVI to obtain land cover data. Processing and analizing of data for mapping soil erosion potential and sediment in the lake TSS conducted at the Laboratory of Geographic Information System (GIS) Department of Soil Science Faculty of Agriculture, Brawijaya University of Malang.

The primary data in this study is obtained from observations of the TSS by 20 points. One observation point three sampling sites, they are: the upper, middle, and base. Each observation point has the coordinate information is intended that such data can be mapped. Each point has a value of observational studies of TSS but the data is not known distribution limits in the area so we need a spatial interpolation. Interpolation used is the kriging method, wherein the method is calculated automatically in the Geostatistical Wizard tools in ArcGIS 9.3. This method is an interpolation by geostatistical grid form. Having obtained the results grid terinterpolasi then the next step is to plot the boundary of Lake Sentani to look deployment TSS values around the inlet and outlet of the lake, accompanied by Pseudo staining (blue - green - red). The next step was to "Reclassify" TSS value data for the purpose of classifying the value of each cell, in this case a class is adjusted by the number of data that can be seen clearly and more easily understood. Stages of the research process as presented in the figure below.

\section{Erosion Prediction}

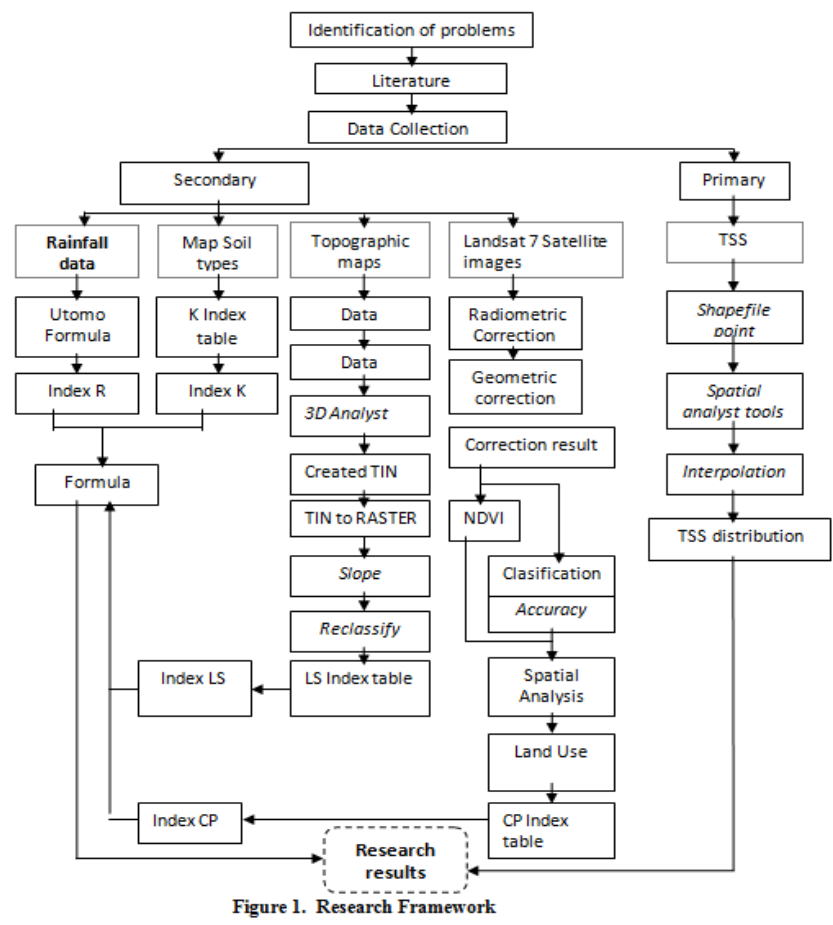

This study is purposed to predict the magnitude of the erosion rate using the Universal Soil Loss Equation (USLE) or Soil Loss Equation General. USLE is an erosion models designed to predict the erosion rate of the long-term average of sheet or gully erosion under certain circumstances. This method is also useful for building and land where non-agricultural use. 
A parametric model for predicting soil erosion from a field has been reported by Wischmeier and Smith (1965, 1978), named for the Universal Soil Loss Equation USLE abbreviated (Arsyad, 2010). In this method, the rate of erosion is a function of six major variables namely: 1) rainfall (R), 2) soil erodibility (K), 3) slope length (L), 4) the steepness of the slope (S), 5) the vegetation cover soil (C), and 6) ground managing (P). In equation form, the erosion rate can be written as follows.

$$
\text { A = R.K.L.S.C.P }
$$

Where:

$\mathrm{A}=$ the amount of soil lost unity land area (ton.ha-1.th-1),

$\mathrm{R}=$ rainfall erosivity factor index $(\mathrm{mm})$,

$\mathrm{K}=$ soil erodibility factor,

$\mathrm{L}=$ slope length factor $(\mathrm{m})$,

$\mathrm{S}=$ slope steepness factor $(\%)$,

$\mathrm{C}=$ factor of vegetation cover, and

$\mathrm{P}=$ factor ground managing

Various parameters that affect the rate of erosion is: rain erosivity (R), soil erodibility (K), slope length (L), slope steepness (S), vegetation cover (C), and pengelolahan ground (P).

\section{Sediment Deposition}

The movement of grains on the sediment surface caused by the water has a different style according to grain size and distribution size of the sediments. For coarse sediment, retaining the style of movement is mainly caused by heavy parikel granules are free. The soft sediment is more likely to withstand the movement rather than the cohesion force of gravity grain itself (driven as a single entity). If the forces acting on a grain of sediment reaching the value increases slightly when it would cause the granules to move, then this condition is a critical state. And if the condition has reached a value of the base shear force channel, the average speed has reached a critical condition. Principle to determine whether there is deposition of sediment in the place such as rivers, water reservoirs, and lakes are as follows:

1. When $\mathrm{K} 1<\mathrm{K} 2$ then occur scour (degradation), in this condition the incoming sediment discharge (Qs) is smaller than the discharge of sediment balance (QSE) in units of time.

2. When $\mathrm{K} 1=\mathrm{K} 2$ then there is a balance (equillibrium transport), in other words the incoming sediment discharge equal to the debit sedien coming out in units of time.

3. When $\mathrm{K} 1>\mathrm{K} 2$ then there is precipitation (agradation), where the incoming sediment discharge (Qs) greater than the balance of sediment discharge (QSE) in units of time where $\mathrm{K}$ is the carrying capacity.

This study was conducted from December 2011 to 2013. Place of measurement and primary data collection is in Sentani Lake Jayapura Papua Province. Map of the study site can be seen on the map below.

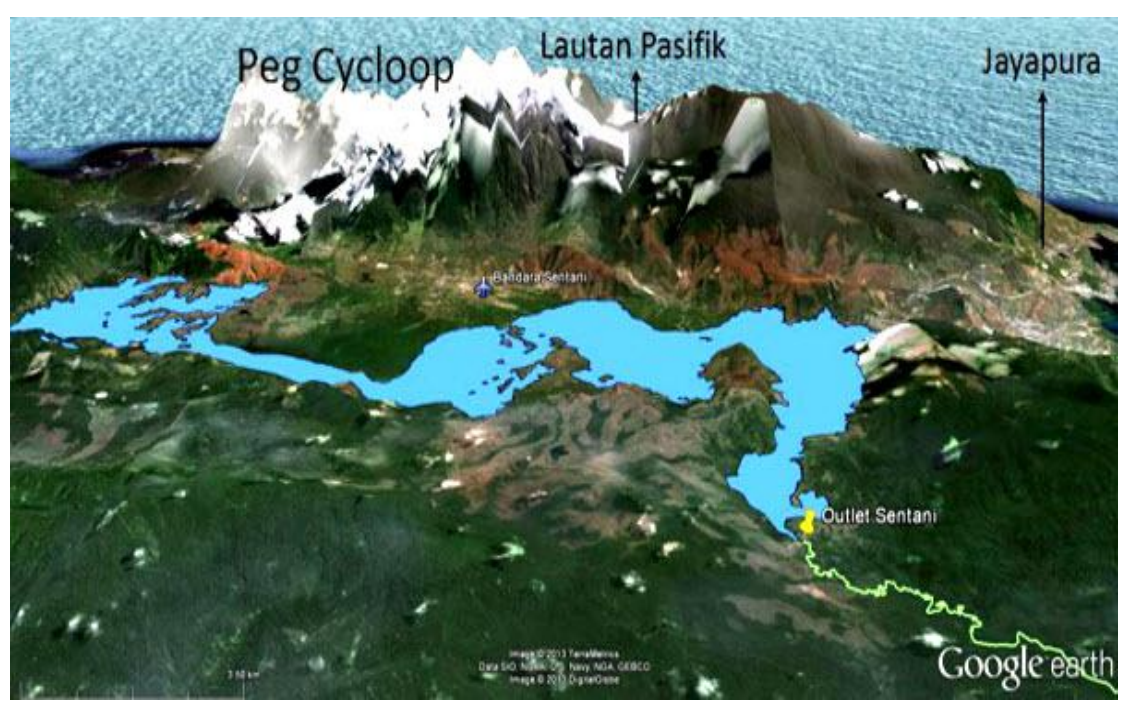

Figure 2. Research Location Map 
The results of the study that has been conducted in substance as follows:

(a) Sentani watershed has generally steep topography, slope percentage of Sentani watershed as presented in Figure 3 shows that in the southern part of the lake has a slope ranging from $3 \%$ to $30 \%$, east and west ranges between $25 \%$ to $45 \%$, and The north area of the lake most rugged ranges from $25 \%$ to $65 \%$. The results of the slope overlay complete of Sentani watershed can be seen on the map below.

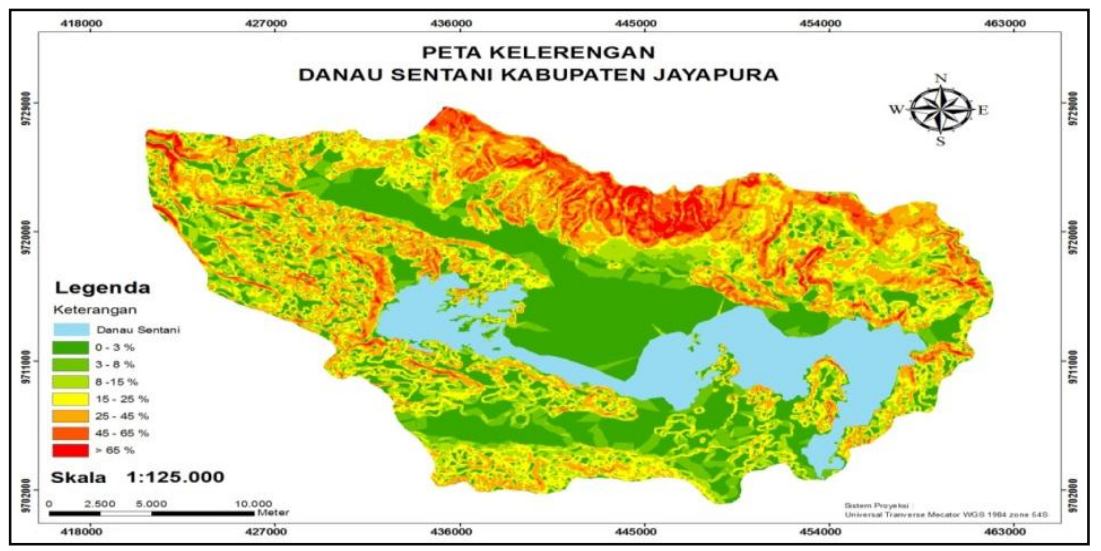

figure 3 : Level of slope Sentani watershed

(b) Results of mapping erosion potential, provide information that the highest erosion potential of between 60 to 180 tons per hectare per year in the north of the lake there are areas that have a high degree of slope, where rocks and sand mining, there is a form of residential and offices.

(c) The concentration of suspended solids (TSS) in the lake between the upper layer and the bottom layer there are significant differences in the upper layer of the TSS concentrations ranging from 20 milligrams per liter to 320 milligrams per liter while the bottom layer of the TSS concentrations ranged from 80 milligrams to 410 milligrams per liter liter. TSS concentration data on the upper layer, middle layer and the bottom layer as presented in Table 1 and a map of the potential erosion of Sentani watershed and TSS concentration distribution in the upper layer as shown on the map 4.

Table 1: Data Concentration Suspended Solids (TSS) water samples of Lake Sentani

\begin{tabular}{|c|c|c|c|c|c|}
\hline $\begin{array}{l}\text { Sample } \\
\text { point }\end{array}$ & $\begin{array}{l}\text { South Latitude } \\
\text { (degrees) }\end{array}$ & $\begin{array}{l}\text { East Longitude } \\
\text { (degrees) }\end{array}$ & $\begin{array}{l}\text { TSS concentration } \\
\text { in the upper layer } \\
(\mathrm{mg} / \mathrm{liter})\end{array}$ & $\begin{array}{l}\text { TSS concentration } \\
\text { in the middle } \\
\text { layer ( } \mathrm{mg} / \text { liter) }\end{array}$ & $\begin{array}{l}\text { TSS } \\
\text { concentration } \\
\text { in the bottom } \\
\text { layer } \\
\text { (mg/liter) }\end{array}$ \\
\hline 01 & -2.600758 & 140.622728 & 307 & 311 & 353 \\
\hline 02 & -2.594560 & 140.615186 & 316 & 320 & 381 \\
\hline 03 & -2.590320 & 140.599933 & 320 & 332 & 380 \\
\hline 04 & -2.593558 & 140.594187 & 299 & 328 & 371 \\
\hline 05 & -2.603046 & 140.617083 & 301 & 317 & 389 \\
\hline 06 & -2.604920 & 140.597760 & 274 & 318 & 381 \\
\hline 07 & -2.610439 & 140.610637 & 213 & 327 & 394 \\
\hline 08 & -2.616958 & 140.598723 & 161 & 278 & 387 \\
\hline 09 & -2.621042 & 140.609032 & 209 & 278 & 396 \\
\hline 10 & -2.627313 & 140.600709 & 67 & 253 & 385 \\
\hline 11 & -2.632764 & 140.607257 & 76 & 294 & 407 \\
\hline 12 & -2.637263 & 140.597571 & 27 & 218 & 364 \\
\hline 13 & -2.646122 & 140.601938 & 30 & 258 & 371 \\
\hline 14 & -2.648981 & 140.594162 & 19 & 188 & 292 \\
\hline 15 & -2.651827 & 140.599893 & 32 & 214 & 306 \\
\hline 16 & -2.654429 & 140.589658 & 36 & 129 & 161 \\
\hline 17 & -2.660425 & 140.591024 & 43 & 132 & 172 \\
\hline 18 & -2.669013 & 140.580254 & 41 & 69 & 95 \\
\hline 19 & -2.674054 & 140.586121 & 48 & 63 & 97 \\
\hline 20 & -2.681423 & 140.582437 & 47 & 65 & 78 \\
\hline
\end{tabular}

Source: primary data, 2013

The results of the distribution of TSS concentrations in the upper layer of Lake Sentani in complete can be seen on the map below. 


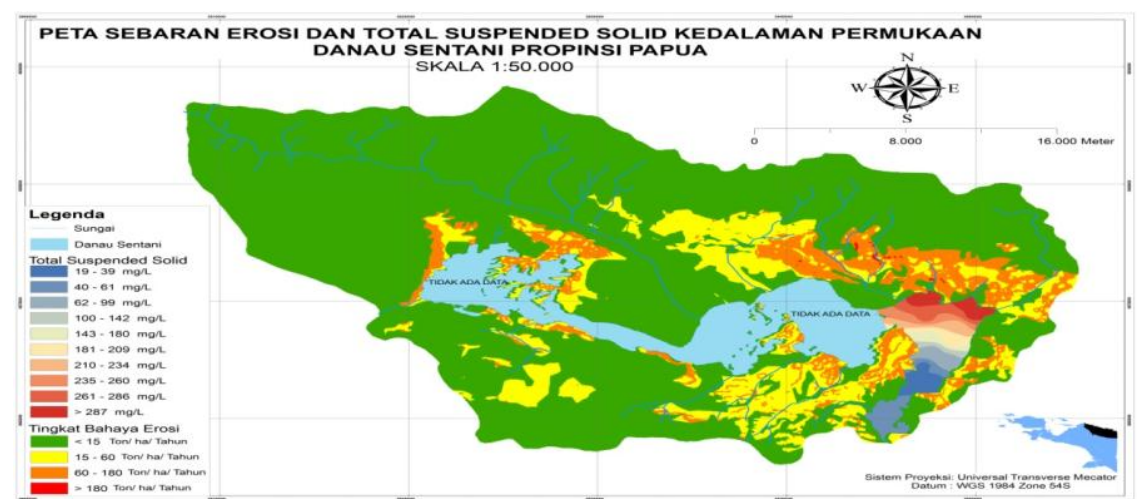

Figure 4: Map of watershed erosion potential and TSS distribution in the upper layer of Lake Sentani

(d) TSS concentration in the upper layer at the inlet is significantly different from the concentration of TSS in the outlet at the inlet ranged from 300 milligrams per liter to 320 milligrams per liter, while in the outlet TSS concentrations ranged from 20 milligrams per liter to 50 milligrams per liter. TSS concentration in the bottom layer at the inlet is significantly different from the concentration of TSS in the outlet at the inlet ranged from 350 milligrams per liter to 390 milligrams per liter, while in the outlet TSS concentrations ranged from 80 milligrams per liter to 170 milligrams per liter, while in the middle of the lake that is the ultimate in having the highest TSS concentrations ranged from 390 milligrams per liter to 410 milligrams per liter. Map of watershed erosion potential and TSS concentrations in the bottom layer of Lake Sentani as presented on the map 5 .

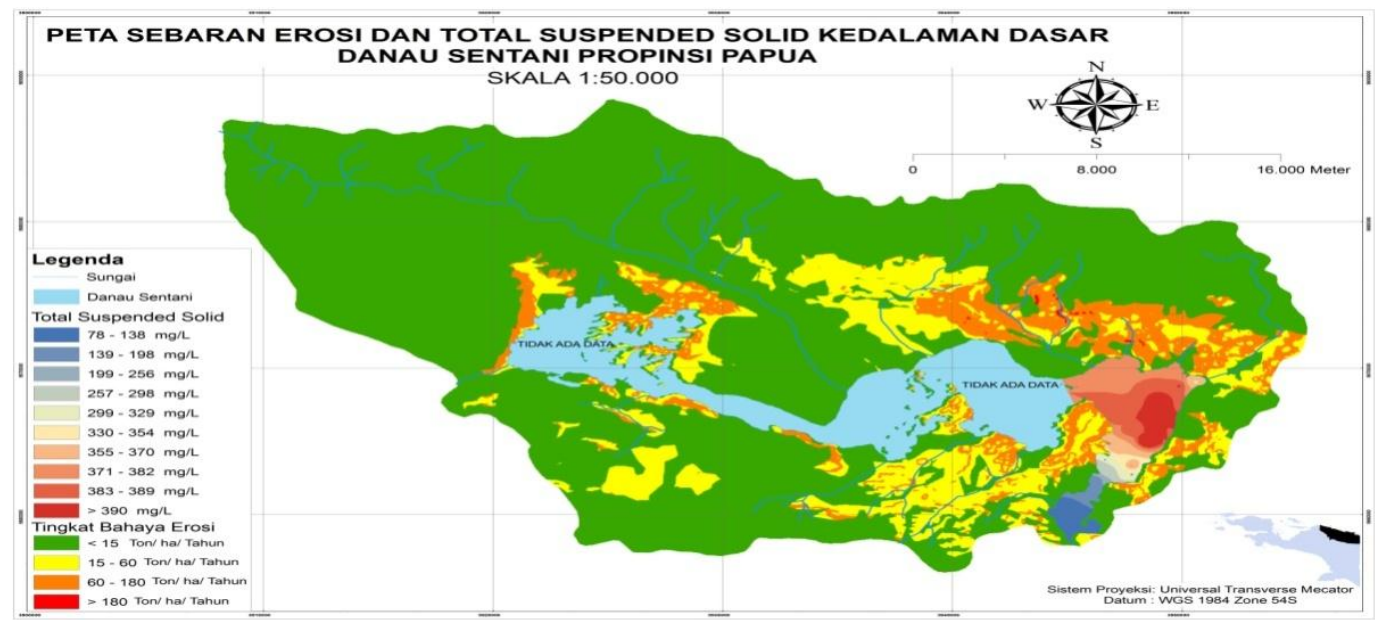

Figure 5: Map of watershed erosion potential and the distribution of TSS bottom layer of Lake Sentani

(e) Water flow rate was measured on two layers near the surface and near the bottom of the lake. There is a significant difference between the flow rate in the second layer, which is the rate of flow in the upper layer ranged from $6 \mathrm{~cm}$ to $22 \mathrm{~cm}$ per second per second while the bottom layer ranged from $2.7 \mathrm{~cm}$ to $16 \mathrm{~cm}$ per second. The rate of flow in the two layers have different characteristics, the flow rate in the upper layer of the greater ranging from the inlet toward the outlet of the lake while the flow in the bottom layer from the inlet to the center of the lake flow rate decreased, but starting from the center toward the outlet rate flow increases. Lake water flow rate on the upper layer and bottom layer as presented in Tables 2, map the distribution of the flow rate on the upper layer and bottom layer as shown on map 6 and 7. 
Table 2: Water Flow Rate of Lake Sentani

\begin{tabular}{|c|c|c|c|c|c|}
\hline $\begin{array}{c}\text { Sample } \\
\text { Point }\end{array}$ & $\begin{array}{c}\text { South Latitude } \\
\text { (degrees) }\end{array}$ & $\begin{array}{c}\text { East Longitude } \\
\text { (degrees) }\end{array}$ & $\begin{array}{c}\text { Depth } \\
\text { (meters) }\end{array}$ & $\begin{array}{c}\text { Flow rate of Surface } \\
(\mathrm{cm} / \mathrm{sec})\end{array}$ & $\begin{array}{c}\text { Flow rate of } \\
\text { bottom }(\mathrm{cm} / \mathrm{sec})\end{array}$ \\
\hline 01 & -2.600758 & 140.622728 & 8.6 & 5.5 & 4.9 \\
\hline 02 & -2.594560 & 140.615186 & 8.2 & 5.9 & 5.0 \\
\hline 03 & -2.590320 & 140.599933 & 8.7 & 6.0 & 5.1 \\
\hline 04 & -2.593558 & 140.594187 & 15.1 & 5.2 & 4.4 \\
\hline 05 & -2.603046 & 140.617083 & 22.4 & 4.8 & 3.2 \\
\hline 06 & -2.604920 & 140.597760 & 32.3 & 4.5 & 3.2 \\
\hline 07 & -2.610439 & 140.610637 & 36.2 & 5.4 & 3.7 \\
\hline 08 & -2.616958 & 140.598723 & 31.4 & 5.6 & 3.8 \\
\hline 09 & -2.621042 & 140.609032 & 35.5 & 6.4 & 3.6 \\
\hline 10 & -2.627313 & 140.600709 & 33.8 & 7.2 & 4.2 \\
\hline 11 & -2.632764 & 140.607257 & 33.1 & 8.5 & 5.0 \\
\hline 12 & -2.637263 & 140.597571 & 32.2 & 8.1 & 5.7 \\
\hline 13 & -2.646122 & 140.601938 & 26.7 & 8.7 & 6.2 \\
\hline 14 & -2.648981 & 140.594162 & 27.4 & 8.4 & 7.1 \\
\hline 15 & -2.651827 & 140.599893 & 23.3 & 12.5 & 7.3 \\
\hline 16 & -2.654429 & 140.589658 & 18.3 & 12.1 & 6.7 \\
\hline 17 & -2.660425 & 140.591024 & 15.2 & 8.8 & 6.8 \\
\hline 18 & -2.669013 & 140.580254 & 16.0 & 8.4 & 7.0 \\
\hline 19 & -2.674054 & 140.586121 & 10.2 & 8.5 & \\
\hline 20 & -2.681423 & 140.582437 & 8.1 & & \\
\hline
\end{tabular}

Table 2: Water Maps of Lake Sentani flow speed at the upper and bottom layers can be explained in complete on the map 6 and 7 below.

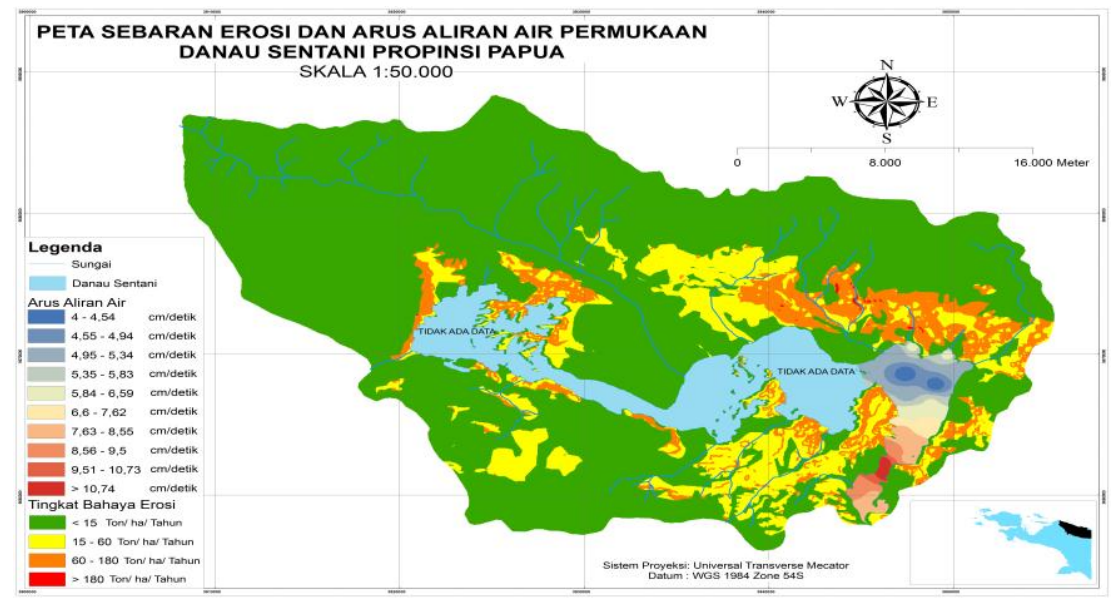

Figure 6: Map of water flow rate distribution on the upper layer of lake sentani

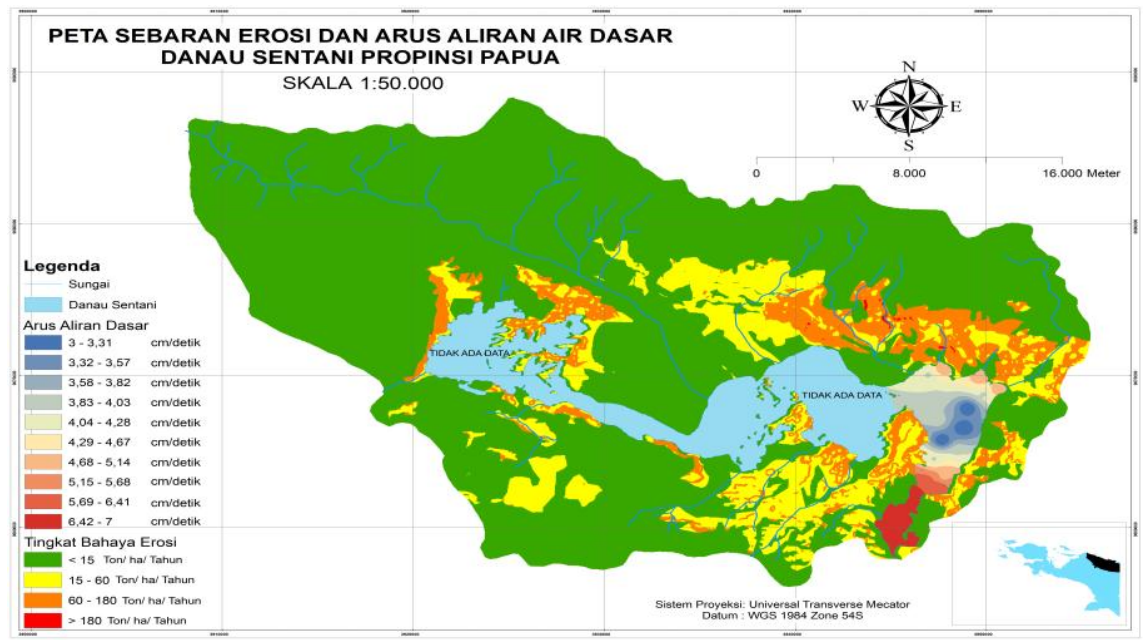

Figure 7: Map of water flow rate distribution on the bottom layer of lake sentani 


\section{Conclusion}

The results of that research to provide solutions to minimize the rate of siltation of Lake Sentani presented some suggestions as follows :

1. Reforestation needs to be done through the planting of trees on open land so that rain water falling into the leaves of trees before it hit the ground, this tree serves as a rate reducer rainwater so that the momentum of the smaller grains, it gives a chance of rain water to seep into the ground it means reducing water runoff in surface runoff so that the kinetic energy is smaller than the kinetic energy of the surface flow in open land, if rainwater seep into the soil not only reduces water runoff but also to the accumulation of water in the soil so that there is adequate water supply in during the dry season .

2. Provision of counseling for people who work as farmers in the watershed so that erosion can be minimized.

3. In residential areas both residential and offices should be considered in order to keep the absorption of water into the soil, for example, yard at home or office should not be coated with cement so that the soil pores are not closed.

4. There should be government regulations so that people should not throw garbage carelessly let alone to the river which empties into the lake, for those who do need firm action from the government for those who do not obey the rules.

5. Research should be conducted on an ongoing basis to monitor the state of Lake Sentani that developments or changes in the lake remain monitored.

\section{References}

[1]. Anonymous, 2011. Pengembangan Model Pemanfaatan Data Penginderaan Jauh untuk Pengelolaan Daerah Aliran Sungai (DAS) dan Danau, The final report of activities 2011, Regional Land Resources Sector, Pusfatja, LAPAN

[2]. Asdak, Chay. (2004). Hidrologi dan Pengelolaan Daerah Aliran Sungai (edisi kedua). Gadjah Mada University Press. Yogyakarta.

[3]. Budiyanto, Eko.(2005). Sistem Informasi Geografis dengan Menggunakan ARC-VIEW GIS. Publisher ANDI. Yogyakarta.

[4]. Collen, D.W \& G.J Miller. 1996. Kimia dan Ekotoksikologi Pencemaran (terjemahan Yanti Koestoer). Publisher Univesitas Indonesia (UI-Press).Jakarta

[5]. JorgensenI. 2009. "Human Induced Eutrophication is Minimized Especially Adverse Effect". Final Report, European Commision

[6]. John Bridge and Robert Demicco. (2008) Earth Surface Processes, Landforms, and Sediment Deposits, Cambridge University Press, 2008

[7]. Jorgensen, S.E. 1990. Erosion and Filtration dalam: Jorgensen \& H. Loffler (Eds). Guidelines of Lake management Vol. 3: Lake Shore Management. International Lake Environmental Committee Foundation Shiga-Kainan Build. Japan.

[8]. Joseph, B.S \& J. Supit. 2002. Tanah dan Lahan. Dalam: Analisis Perubahan Tata Guna Lahan Daerah Aliran Sungai Tondano Menuju Pembangunan Berkelanjutan di Sulawesi Utara

[9]. Liu J., Hirose T., Kapfer M. and Bennett J., 2007, Operational Water Quality Monitoring over Lake Winnipeg Using Satellite Remote Sensing Data, Our Common Borders - Safety, Security, and the Environment Through Remote Sensing October 28 November 1, 2007, Ottawa, Ontario, Canada

[10]. Lehmusluto,P.,2006. "From Assumptions to Knowledge-Based Water Resources Management Ecological and Environmental Issues of Lakes as Examples". Proceeding on International Seminar Celebration the 70th Anniversary of the Research Center for Water Resources, Bandung

[11]. Lehmusluto,P., B.Machbub, Bukit,.N.T., Rusmiputro. S., F.Achmad., L.Boer., Brahmana, S., 1995. "National Inventory of The Major Lakes and Reservoir in Indonesia”, Expedition Indodanau

[12]. Mostafa M.M. and Soussa H.K., 2006, Monitoring of Lake Nasser Using Remote Sensing and GIS Techniques, ISPRS Commission VII Mid-term Symposium "Remote Sensing: From Pixels to Processes", Enschede, the Netherlands. 8-11 May 2006

[13]. Machbub,B., Fulazzaky, M.A., Brahmana, S. dan.Yusuf, I.A., 2003. "Eutrophication of Lakes and Reservoir and Its Restoration in Indonesia". Journal of water research Vol.17(50), Puslitbang Pengairan, Bandung. 